\title{
TOWARD A GLOBAL ORCHID TAXONOMIC NETWORK
}

\author{
Franco PuPULIN \\ Lankester Botanical Garden, University of Costa Rica \\ P.O. Box 302-7050 Cartago, Costa Rica \\ Harvard University Herbaria, Cambridge, MA, U.S.A. \\ Marie Selby Botanical Gardens, Sarasota, FL, U.S.A. \\ franco.pupulin@ucr.ac.cr
}

\begin{abstract}
The genesis and early establishment of the EPIDENDRA project are reviewed, retracing the scientific, ethical and political reasons that defined its actual shape and contents. The taxonomic structure of the global orchid network, its systematic framework and nomenclatural implications are discussed. The actual figures of the database are presented, and the lines of its future development are pointed out.
\end{abstract}

RESUMEN: Se revisan la génesis y las etapas iniciales del desarrollo del proyecto EPIDENDRA, recapitulando las razones científicas, éticas y políticas que contribuyeron a definir su forma y contenidos actuales. Se discuten la estructura taxonómica de la red global de orquídeas, su marco sistemático e implicaciones nomenclatoriales. Se presentan los hechos y números actuales de la base de datos y se esbozan las líneas de su desarrollo futuro.

KEY wORDS: databases, Orchidaceae, botanical nomenclature, EPIDENDRA, history of science

"S'il publie lui-même ses Orchidées, la moitié sera déjà connue [...]. On sait qu'il set totalement impossible de produire hors de l'Europe un travail parfait [...]. Veuillez exposer ces considérations à votre ami et lui dire que je lui offre de publier ses nouveautés sous notre mutuelle autorité."

"If he would publish his orchid species by himself, half of them would be already known [...]. Anybody knows that it is impossible to produce a perfect work outside Europe [...]. Tell to your friend that I offer him to publish his novelties under our shared authority."

Letter by H. G. Reichenbach intended for J. Barbosa Rodrigues

March 1877

Apologia pro opere meo. Looking back to the discussions that led to the original conception and design of EPIDENDRA, the global taxonomic network created and maintained by the Lankester Botanical Garden (LBG) at the University of Costa Rica (UCR), it is hard to believe that more then ten years have elapsed. It is now time to try explaining the genesis of this project and the main forces that molded it into its actual shape and contents and to point out the lines of its future development.
Basically meant to respond the needs of the orchid researchers working at LBG as a sort of digital surrogate of a documentary archive, EPIDENDRA incorporated scientific, ethical and political reasons that were not apparent - or at least not deliberately planned - at the beginning. The reconstruction of these reasons and the general significance of EPIDENDRA, as I present it below, are therefore the products of a largely a posteriori consciousness. Notwithstanding its imperfections and partiality, the actual structure of the global orchid taxonomic network reflects a scope that goes beyond the simple organization of botanical information as it was originally conceived to convert it into a scientific tool that helps tens of orchid students around the world every day to improve the biological inventory they are committed to carry out. When we look at today's figures of EPIDENDRA's on-line visitation, it is noteworthy that the databases are mostly accessed by students working in Neotropical countries, reflecting not only the actual focus of the site requests for taxonomy of tropical American orchids but also the progressive satisfaction of information requirements by local scientific communities. As one of the conceptual authors and a worker of EPIDENDRA, I am not in the position of judging the magnitude of the results, but I can at least relate where we are along this process and why we are there. 


\section{An exemplary story}

In 1840, as a worldwide recognized specialist in Brazilian botany, Carl Friedrich Philipp von Martius began editing Flora Brasiliensis, a monumental work for which he sought the assistance of the most distinguished botanists of the time to write monographic treatments of various families. When the work was eventually concluded by Ignacio Urban in 1906, 65 naturalists had contributed to the Flora: 38 German botanists, five Austrians, five British, five Swiss, four French, two Belgians, two Danes, two Czechoslovaks, a Dutch and a Hungarian (Mello Leitão 1937). None of the contributors was a Brazilian.

Concerning orchids, however, Brazil had then a distinguished student, João Barbosa Rodrigues (Fig. 1A), who in 1870 had presented a work in three volumes with descriptions in Latin and French of hundreds of new orchid species. A copy of the still unpublished work was sent in 1871 to August Endlicher - Martius' successor as the main editor of the Flora Brasiliensis - who, in turn, showed Barbosa Rodrigues' manuscript to Heinrich Gustav Reichenbach (Fig. 1B), the botanist in charge of Orchidaceae. It was obvious that a reasonable treatment of the orchid flora of Brazil was impossible without the specimens and field notes by Barbosa Rodrigues, and Reichenbach tried to obtain them. When in 1877 Barbosa Rodrigues eventually sent to press his "Genera et species orchidearum novarum", he published the extract of a letter by Reichenbach directed to his friend Anders Fredrik Regnell (Barbosa Rodrigues 1877). With a tone that one could see as coldly cynical - or crudely honest - the German professor asked Regnell to convince Barbosa Rodrigues to give up its publication, adducing the impossibility for a Brazilian botanist to publish an accurate work without access to the types and literature only available in Europe (Fig. 2). Reichenbach's crude realism illustrates a scientific situation common during the nineteenth century general aversion to having scientific efforts carried out locally (Neiva 1929; Sá 2001).

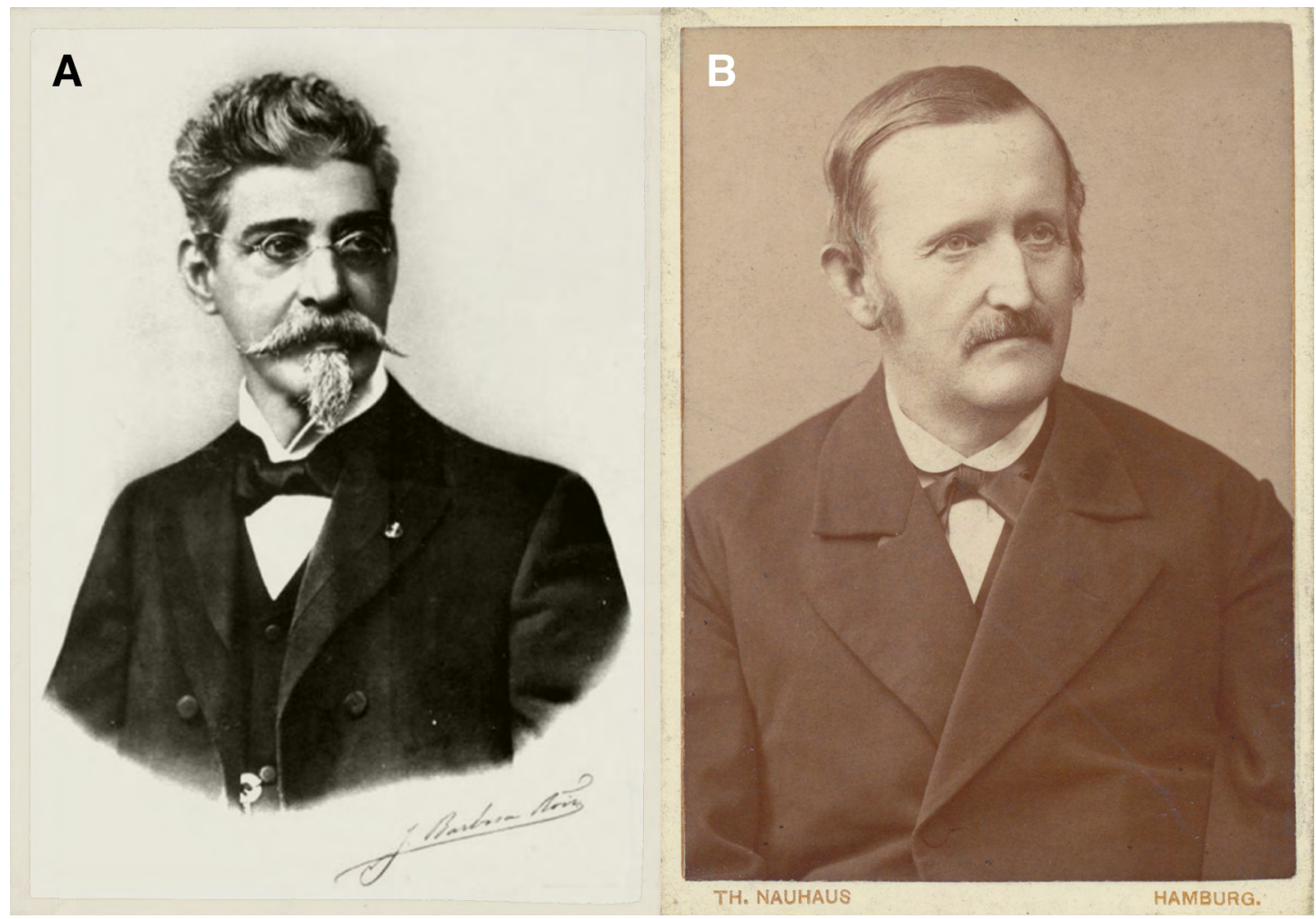

Figure 1. Two great orchidologists. A - The Brazilian João Barbosa Rodrigues (1842-1909), lately Director of the Rio de Janeiro Botanical Garden. B - The German Heinrich Gustav Reichenbach (1823-1889), Professor of botany and Director of the botanical gardens at Hamburg University. 


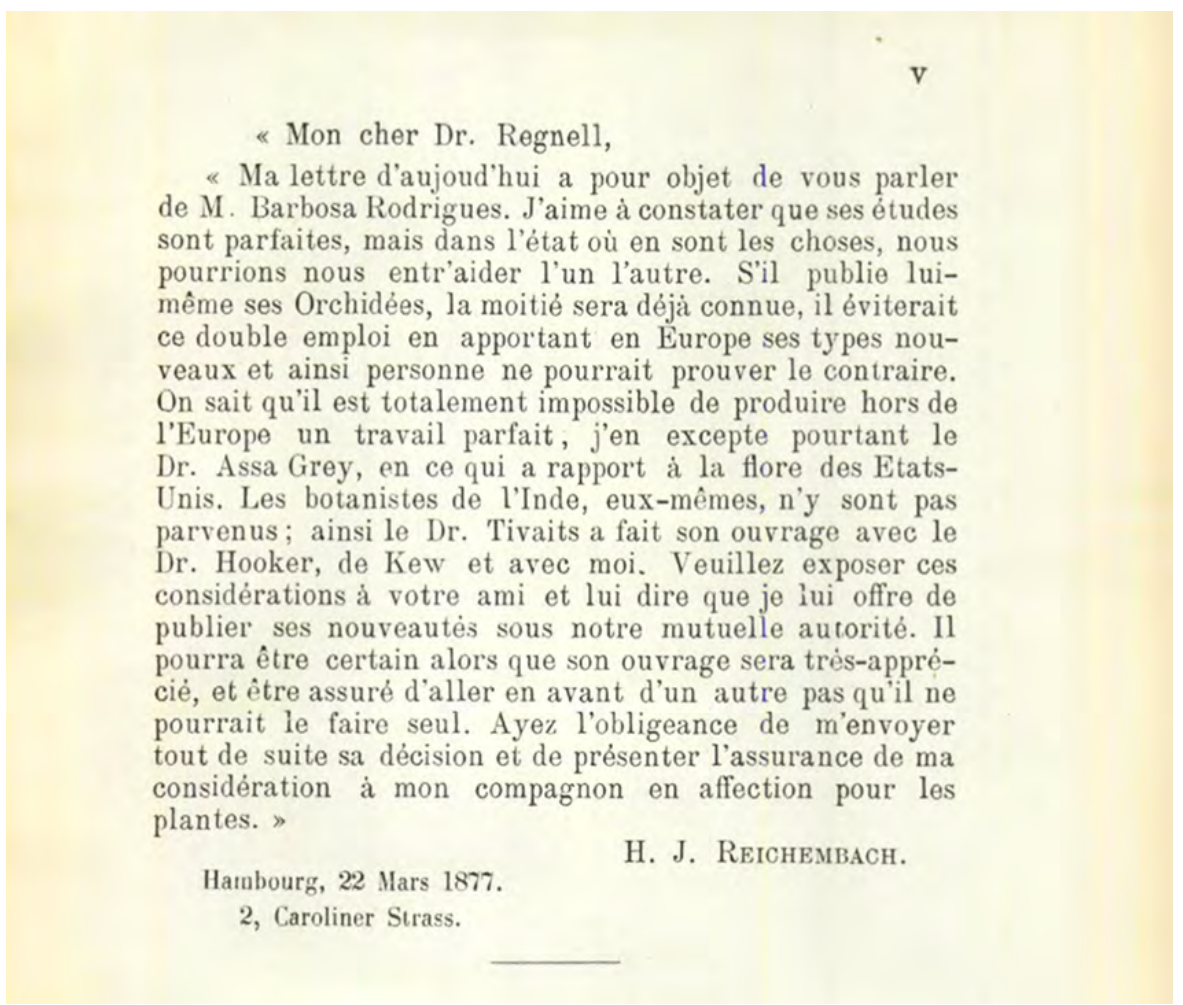

FIgurE 2. Extract from the letter by Reichenbach to Regnell, dated 22 March 1877 (from Barbosa Rodrigues 1877).

It is a fact that the essential information on the identity of the organisms native to the biologically richest regions of the planet was mostly stored in Europe, and Reichenbach himself (cited in Barbosa Rodrigues 1877) considered as the only exception to this rule the herbarium of North American plants gathered at Harvard by Professor Asa Gray. Study of the biological diversity in the tropical regions has been traditionally hampered by the lack of an appropriate information system - including plant museums and modern herbaria - and the absence of significant historical libraries. This has been an impediment to a vaster documentation of biological variation, which is required for a full understanding of living diversity, ecosystem dynamics and their conservation.

If one looks at the botanical institutions that played an important role in global documentation of plant diversity until the end of nineteenth century, it is easy to see that they were almost exclusively located in those European countries that had a significant colonial history (Fig. 3A) as a result of the scientific and economic interests they had in the exploration and exploitation of their overseas possessions. Half a century later, botanical predominance spread across the Atlantic to include several distinguished institutions in North America and a few other research centers across the world, mostly in the cultural areas where English was spoken. A simple view of the "world map of botanical excellence" in the first half of the twentieth century (Fig. 3B) clearly reveals that the countries lying in the tropical regions of the Earth, which we could define as "culturally young" areas, are completely absent from this scene. Until the last decades of the second millennium, botany in general, and more specifically the building and maintenance of large repertoires of specimens, books and other materials necessary for the interpretation of plant diversity, largely remained a business of developed countries.

Of the almost 400,000 plants species recorded on Earth, three quarters live in the tropical regions, where rain forests support the greatest diversity of living organisms and the inventory of orchid diversity is incomplete. The paradox, however, is that while a better 

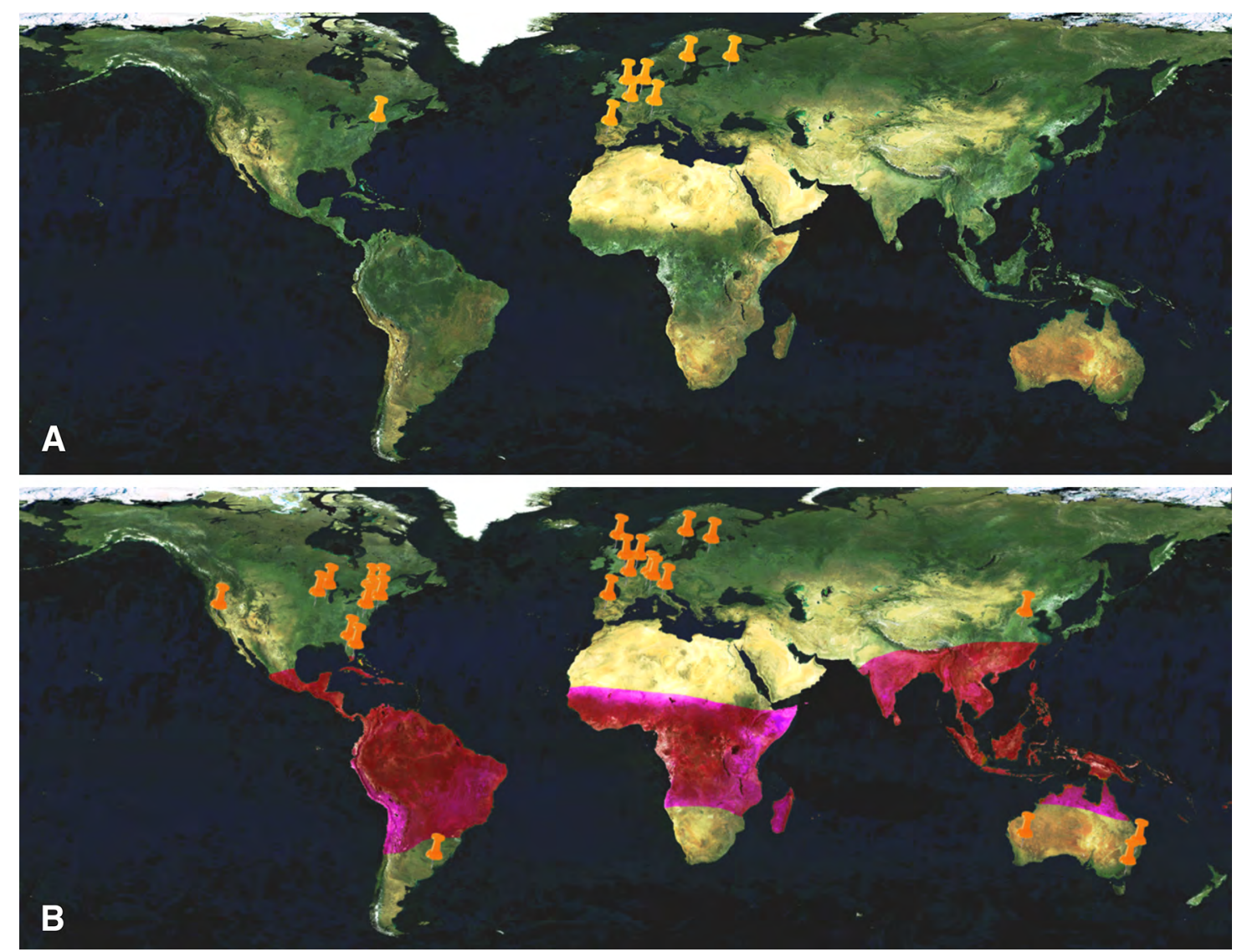

FIGURE 3. Important centers for plants documentation of global interest. A - During the second half of nineteenth century. B - In the first decades of twentieth century. The red areas on the map correspond to regions with tropical vegetation.

documentation system is needed for the identification, comparison and management of the much more diverse tropical floras, and the need for floristic research in the tropics is greater than at any other time in modern history, most of the essential documents and the globally important collections necessary for the interpretation of floristic mega-diversity are stored in developed countries of the temperate regions (Fig. 4). The history of orchidology in Costa Rica is a perfect example of this paradox.

\section{Naturalists and botanists}

Costa Rica is well known as one of the richest regions in the world in plant species and - at least compared to other floristically diverse areas - a well botanized country. Knowledge of the Costa Rican flora was largely attributable to the continuous presence of a varied group of resident naturalists who carried out botanical exploration and collection since the second half of the nineteenth century. The list of naturalists who lived in Costa Rica begins with the Germans Carl Hoffmann (1833-1859) and Alexander von Frantzius (1821-1877), followed by Auguste R. Endrés (18381875), French by birth but German by culture, and the Swiss Richard Pfau (-1897), who established an orchid firm in San José around 1870. During the 1870s the Swiss Henri Francois Pittier (1857-1950) and Pablo Biolley (1861-1908) came to Costa Rica, who were soon joined at the Instituto Físico-Geográfico and the Costa Rican Museo Nacional by Adolphe Tonduz (1862-1921), another Swiss, the German brothers Alexander Curt (1881-1971) and Alfred Brade (18671955), the Alsatian Carl Wercklé (1860-1924), and the Costa Ricans Anastasio Alfaro (1865-1951), Alberto Manuel Brenes (1870-1948) (Fig. 5A), and the young Otón Jiménez (1895-1988) (Fig. 5B). Together 


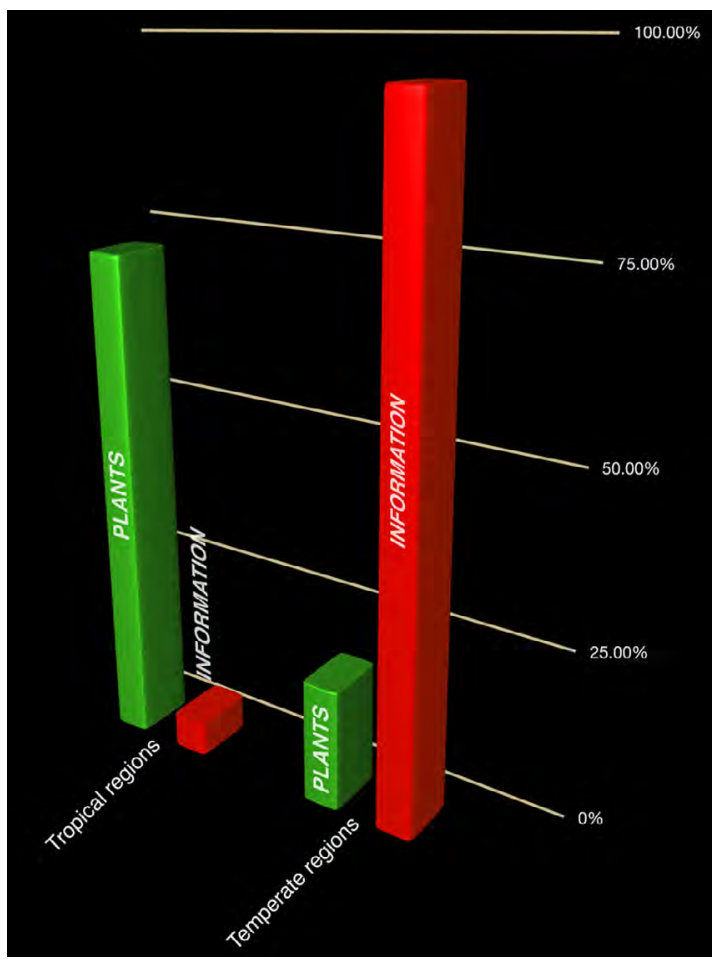

FIGURE 4. Number of plant species versus number of stored type specimens in tropical and developed countries.

they formed a herbarium that, at the beginning of the twentieth century, "was unequalled below the Río Grande del Norte" (Standley 1937). Under the unselfish patronage by Amparo López-Calleja de Zeledón (1870-1951), most of them also contributed specimens to be sent for determination in Europe. Then, during the first decades on twentieth century, the list includes the British Charles Herbert Lankester (1879-1969) (Fig. 5C), his good friend and companion in botanical excursions, the Costa Rican Alfredo Sancho (1876-1929), and Juvenal Valerio Rodríguez (1900-1971) (Fig. 5D), who eventually became one of the founders of the Pan-American Agricultural School "El Zamorano" in Honduras (for a review of orchidrelated activities in Costa Rica until the mid-1900s, see Ossenbach 2009).

When studying the orchid specimens gathered by this trained group of individuals, it is evident that they were not collected randomly. They knew the orchid flora of Costa Rica, and selectively prepared specimens that were mostly unknown by science. Of the 165 orchid specimens collected by Wercklé and cited by Schlechter (1923) in his work on the orchid flora of Costa Rica, more than half (84) were new to science at the time of their discovery (Pupulin 2010). In the same work, Schlechter described 92 new species from the collections of Brenes alone (Barringer 1986). Among the orchid specimens sent by Lankester to his correspondents in Europe and in the United States, 113 were described as new species (Pupulin \& Romero 2003). Considering that not a single orchid species from Costa Rica bears the authorship of Biolley, the Brade brothers, Brenes, Jiménez, Lankester, Pittier, Sancho, Tonduz, Valerio, and Wercklé, it is perhaps obvious to ask why they did not make the next logical step in botanical research - naming and describing their orchid collections. The answer is probably simple: they did not have access to types and other critical specimens, original literature and illustrations, etc. with which to compare their new findings. They had no other choice but to form small "scientific societies" with botanists of the developed world, who took charge of the scientific descriptions of the orchid flora of Costa Rica. Heinrich Gustav Reichenbach (Fig. 6A), Robert Allen Rolfe (Fig. 6B), Rudolf Schlechter (Fig. 6C), Oakes Ames (Fig. 6D) and Fritz Kränzlin permanently bound their names to the orchids of Costa Rica. It was inevitable that, within the framework of these societies, the role of the resident naturalists would be mostly interpreted and sometimes bitterly perceived - as that of "plants providers" or, simply, collectors. "I begin to consider these cabinet-celebrities as vampires nourishing their inflated fame at the cost of the lifeblood of those poor fools they condescendingly call 'collectors': these words were written in 1874 by A. R. Endrés, probably the greatest orchidologist who ever worked in Costa Rica (Ossenbach et al., in press).

Things were not substantially different in Costa Rica at the end of the millennium. The research carried out by Dora Emilia Mora-Retana, the first national academic orchidologist and director of LBG for over 25 years, was mostly done in cooperation with foreign students, notably John T. Atwood, who through his activity as the director of the Orchid Identification Center at the Marie Selby Botanical Gardens had access to modern herbaria and library facilities. Their common work culminated in the publication of the Maxillariine and Oncidiinae treatments for the Flora Costaricensis (Atwood \& Mora-Retana 1999), the results of an advantageous and 

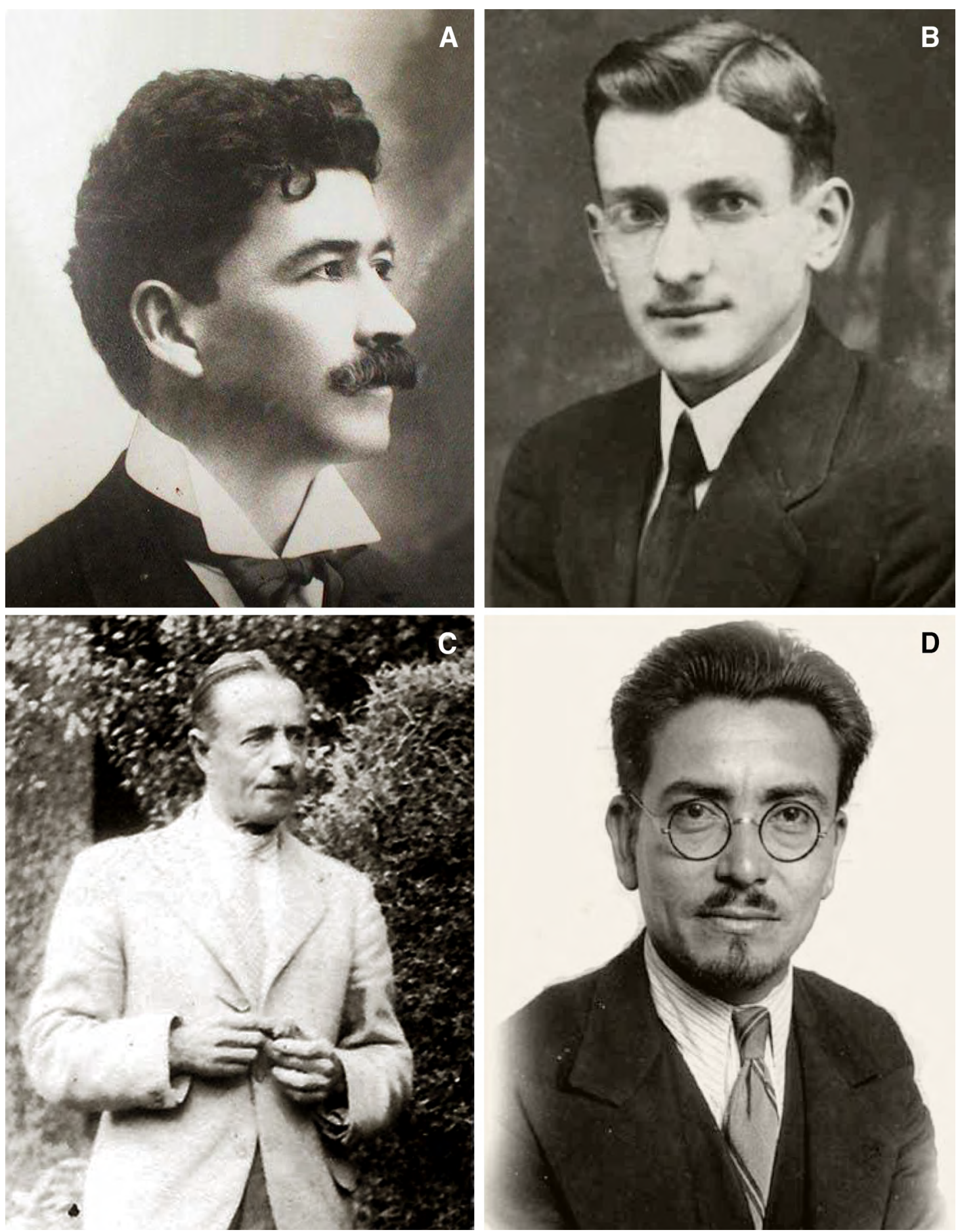

FIgURE 5. Naturalists who collected new orchid species in Costa Rica. A-Alberto M. Brenes. B - Otón Jiménez. C - Charles H. Lankester. D - Juvenal Valerio. 

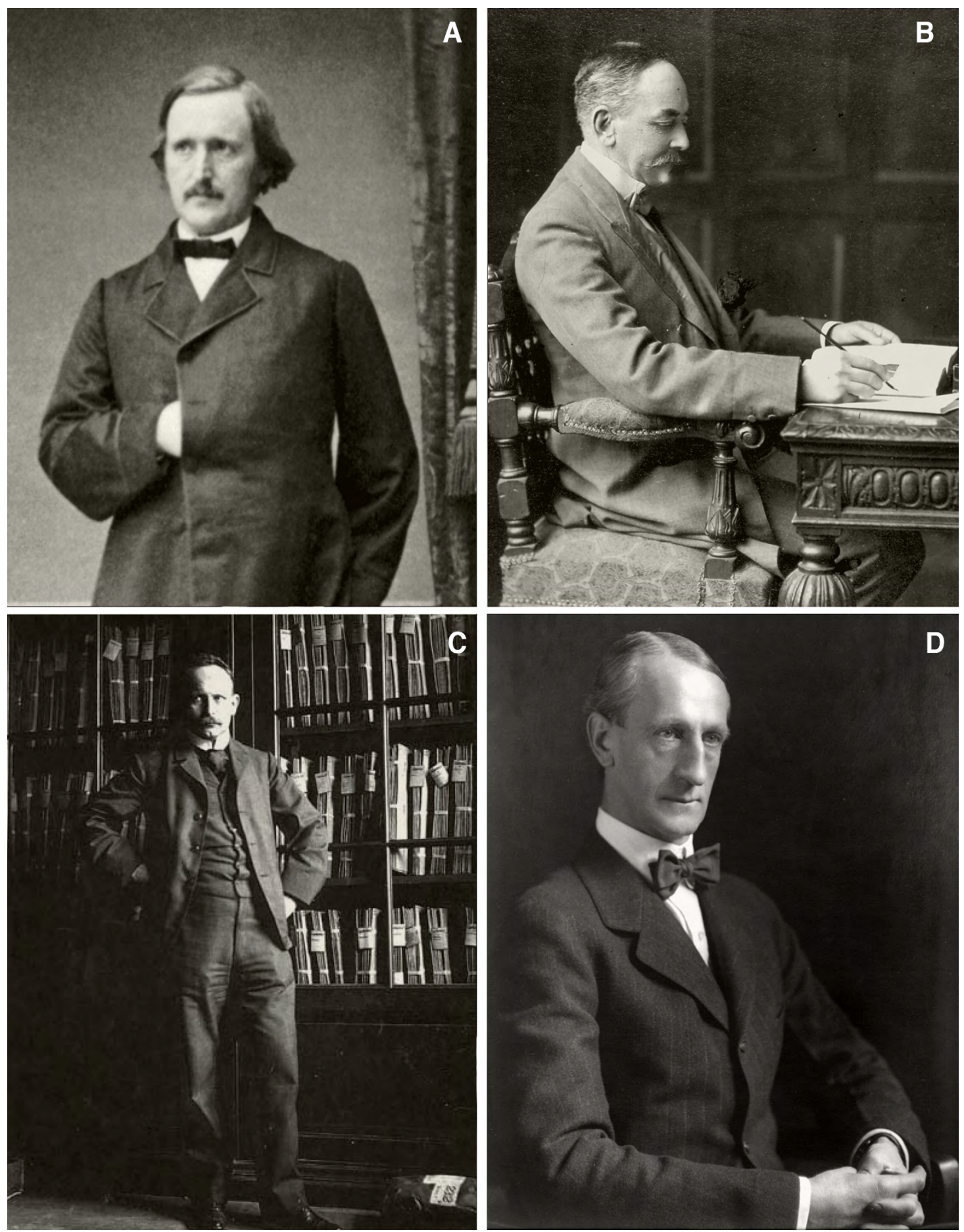

FIgURE 6. Botanists who described new orchid species from Costa Rica. A-Heinrich Gustav Reichenbach. B - Robert Allen Rolfe. C - Rudolf Schlechter. D - Oakes Ames. 
necessary cooperation, as Mora-Retana's observations relied on the scrutiny of materials and information not available in Costa Rica.

When, in 2001, I was hired to work as an orchid researcher at LBG, the taxonomic archives of the center were still limited to two file cabinets, and there was no specialized library. Although the scarcity of economic resources has been mostly identified as the principal factor limiting the growth of the biological sciences in tropical countries, we discovered instead that the major limiting factor was the scarcity of information (Pupulin \& Warner 2005).

\section{The advent of the Internet}

Images of herbarium specimens in the form of photographs, slides, photocopies, etc., with a special emphasis on nomenclatural types have long been used as complementary materials for taxonomic studies. Early examples of extensive image collections of type specimens date back to the 1930s (i.e., the photographs of European types taken by J. Francis Macbride, now available from the web site of the Field Museum in Chicago), but it was not until the advent of digital data capture in the last two decades that the information sources represented by biological collections kept in developed countries began to be effectively disseminated. Toward this end the project CROTYPES, a joint effort by the LBG and the Oakes Ames Orchid Herbarium, digitized the nearly 800 type sheets of Costa Rican Orchidaceae, probably the richest repository in the world (Pupulin \& Romero 2003). Analogous projects were carried out in subsequent years by LBG researchers at the herbaria of the Marie Selby Botanical Gardens, the Royal Botanic Gardens, Kew, the Real Jardín Botánico of Madrid, the Linnean Society of London and the Natural History Museum in Vienna. Rare-to-find, important texts for the interpretation of the orchid flora of Costa Rica were also digitized in the last ten years.

It was a fortunate circumstance that, when the structure of EPIDENDRA was originally discussed, the use of the Internet was already established as the main electronic platform for data interchange. Since 1982 the Missouri Botanical Garden had established with Tropicos its primary supporting database for botanical taxonomic research, with an Internet page that today provides open worldwide access to over 1.2 million plant names (with synonymy, types, distributions, references, and cross-referenced specimen records; Tropicos 2012). In the mid-1980s the production of an electronic version of Index Kewensis gave rise to the International Plant Names Index (IPNI), a database of the names and associated basic bibliographical details of seed plants, ferns and fern allies, a collaborative effort among the Royal Botanic Gardens, Kew, Harvard University Herbaria and the Australian National Herbarium. Currently, it holds more than 1.6 million name citations, 42,000 authors and almost 17,000 publications (IPNI 2012). Later, Rudolf Jenny made public his personal orchid literature database, BibliorCHIDEA, which contains most of the existing journal articles, books and preprints on Orchidaceae. With its 150,000 entries, it is maintained today by the Swiss Orchid Foundation at the University of Basel, which also added the World Orchid Iconography, including almost 80,000 records for over 10,000 orchid species. Taken five years to complete, the Royal Botanic Gardens, Kew, published in 2006 the World Checklist of Selected Plant Families as a searchable electronic database consolidating over 200,000 names. The project has now become an international collaborative program with more than 150 contributors throughout the world who update nomenclature and identification of the species (WCSP 2012). Several other databases arose in the last decade, some of them specifically devoted to Orchidaceae, such as the Internet Orchid Species Photo Encyclopedia compiled by Jay Pfahl, the Orchid Picture Reference Database created by the London Orchid Society (Ontario, Canada) with almost 140,000 links to pictures found in over 1500 picture sources. Others have a more regional approach (such as Orchidaceae from Central Africa, including scientific names, distribution data, images, identification keys, links and references). Still others focus on genera, such as Nina Rach's The Sobralia Pages and The Stanhopea Pages, with images, and information on habitat and culture.

Until recent years, one common characteristic of nomenclatural databases was that they were mainly built as a reference system designed to provide references to plant names, basionyms and synonyms, nomenclatural types and lists of exsiccata for selected regions, allowing botanists to gain ready access to the authors of names, titles of key publications 


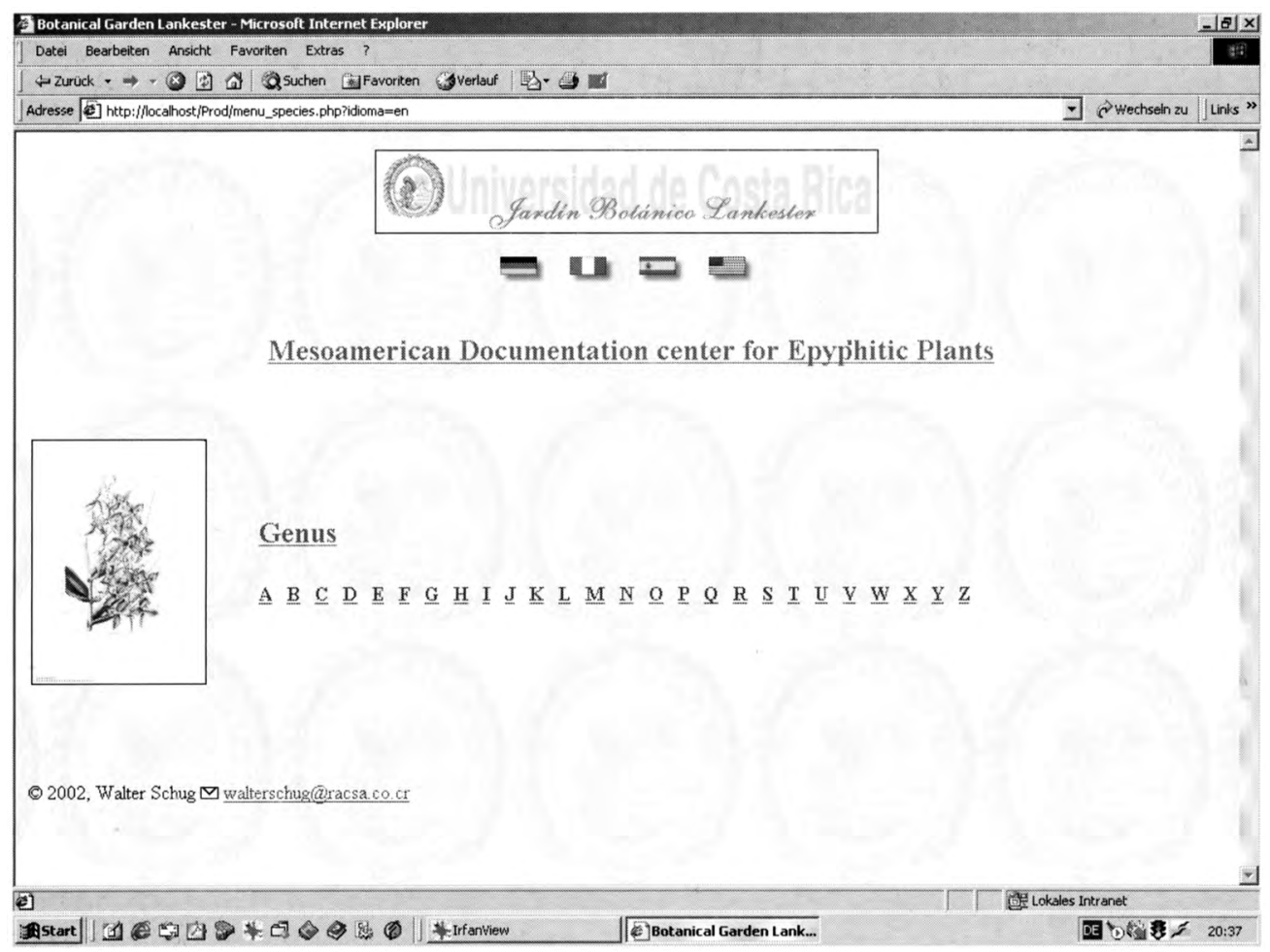

FIGURE 7. A screenshot of a page from the first version of EPIDENDRA website.

and, indirectly, to locations of type specimens. The users, however, are referred to physical documents (protologues and other critical publication, types and other materials associated with the types) that are not available electronically. In this sense, the electronic tools for the retrieval of botanical information presuppose direct access to the sources through libraries and herbaria services. This is often not the case in tropical countries, where facilities are often insufficient and where the lack of historical libraries and the relatively modernity of the existing herbaria represent a major obstacle for botanic research when concerned with the retrieval of historical information (Gómez-Pompa \& Nevling 1988; Pupulin \& Warner 2005; Pupulin 2007).

In 2002, the conceptual discussion about the characteristic of JBL databases was substantially concluded, and the intranet version of EPIDENDRA began its life. The name of the database, the plural of Epidendrum, was an allusion to the old name under which Linnaeus knew all the epiphytic orchids from the tropics. As a mainly internal research tool, EPIDENDRa was designed to gather and make electronically available all the materials from the garden's collections: the documentation center, the library, the living plant collections and the ancillary collections (spirit, pollinaria, slides, scans, material in silica). When EPIDENDRA eventually opened to the public with the launch of its first web page in 2003 (Fig. 7), the system focused on the direct availability of the original sources as its main attraction (Schug 2003). Since then, the database has been profoundly modified to satisfy the needs of a more demanding public and simplify its access and use, but the conceptual structure of EPIDENDRA has remained almost unchanged until today.

\section{EPIDENDRA's taxonomy}

In the past, the debate on biological databases mainly focused on the best model to be used in organizing taxonomic data from literature and other sources to avoid oversimplification and reflect the elasticity of taxonomy as well as alternative taxonomies (see, e.g., Berendsohn 1997; Conn 2003). 
As taxonomic information may become rapidly outdated in the tropics, we hoped to be able to build a system designed to reduce taxonomic decisions in the database to a minimum as an alternative to the necessity to train specialized staff and thereby increase the cost of the effort.

As botanical names of any rank, independent of their priority and meaning, are equivalent in weight, we visualized a horizontal structure wherein all species names were equally considered: names were simply treated as equivalent doors to gain access to relevant taxonomic information. Our intention was to provide unrestricted access to documentary sources, and a simple but accurate system of cross-referenced synonyms seemed to be the best way to guarantee the easiest access and avoid difficult (and sometimes useless) taxonomic controversies. According to this plan, we were confident that the taxonomic work and therefore the need of specific skills and expertise could be basically reduced to verification of heterotypic synonymies recorded in taxonomic literature through a careful study of original type materials (Fig. 8A). Our plan soon proved to be too optimistic.

First, taxonomic literature is plagued with errors. Species names can be ineffective, illegitimate, invalid or simply inexistent; the simple priority rule in the application of names has often been ignored or distorted, mainly when old and obscure scientific names are concerned; spelling is frequently incorrect; and old and new homonyms - to be disentangled - pop up with unexpected frequency. The uncritical "horizontality" of our system, which should have allowed a sort of automatic implementation of the database, became a taxonomic nightmare. This also applies to supposed automatic, homotypic synonymy: irrespective of accepted generic circumscriptions or before such considerations, can generic names confidently be used according to the provisions of the Code? Are they effective, legitimate, valid?

Furthermore, with the inclusion in the database of flower photographs, as well as historical and modern botanical illustrations and drawings, PDF files of relevant literature, and images of the pollinaria, we met another conceptual difficulty. Synonymous names have no reality as living organisms: flowers, pollinaria, and even preserved genetic samples only belong to good species, associated with a correct and accepted name.
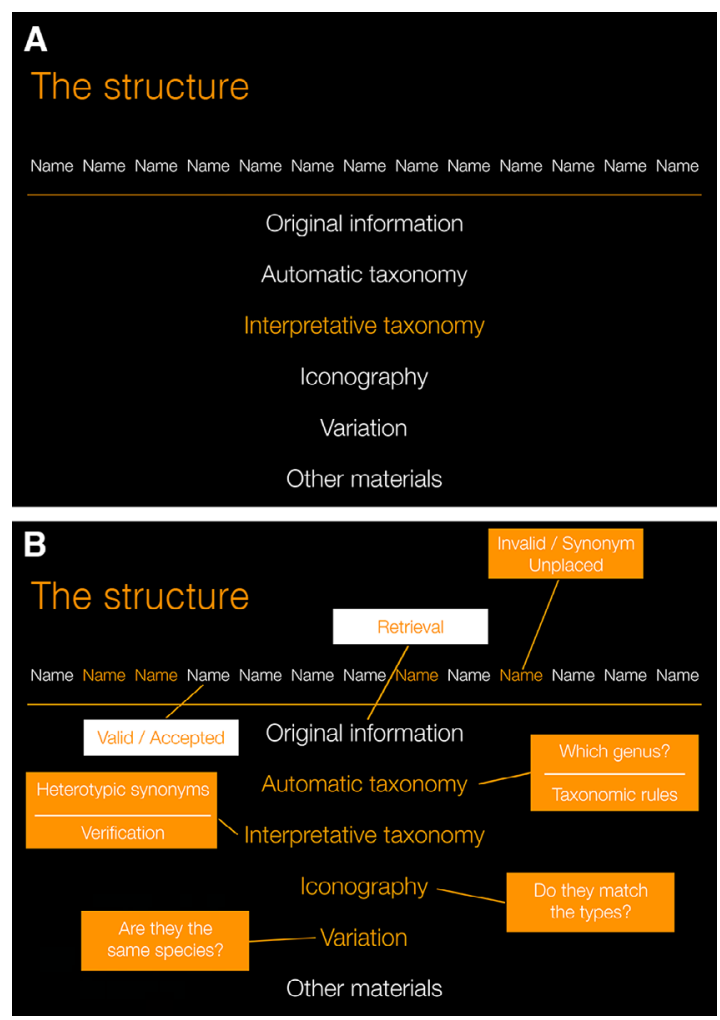

FIgURE 8. The conceptual structure of EPIDENDRA's taxonomy. A - The originally expected, horizontal, mostly uncritical model. B - The actual, verified model. Orange boxes and letters indicate areas that are dependent on taxonomic decisions.

One step beyond the index, the individual species-files of EPIDENDRA must belong to one of two categories: an accepted name (including all the ancillary iconographic materials) or a synonym, which is just a nomenclatural door to be referred to the accepted name.

It is now quite clear for us that, to maintain an updated and critically evaluated taxonomy and relative taxonomic history, the adoption of one or more alternative taxonomies cannot be avoided, even when the taxonomic system is unofficial (Fig. 8B).

\section{The systematic framework}

Again, EPIDENDRA was fortunate in coinciding with the publication of Genera Orchidacearum, the greatest effort ever made by the scientific community at producing a robust and natural account of the orchids at the generic level, incorporating molecular data in a truly phylogenetic classification, which eluded plant 


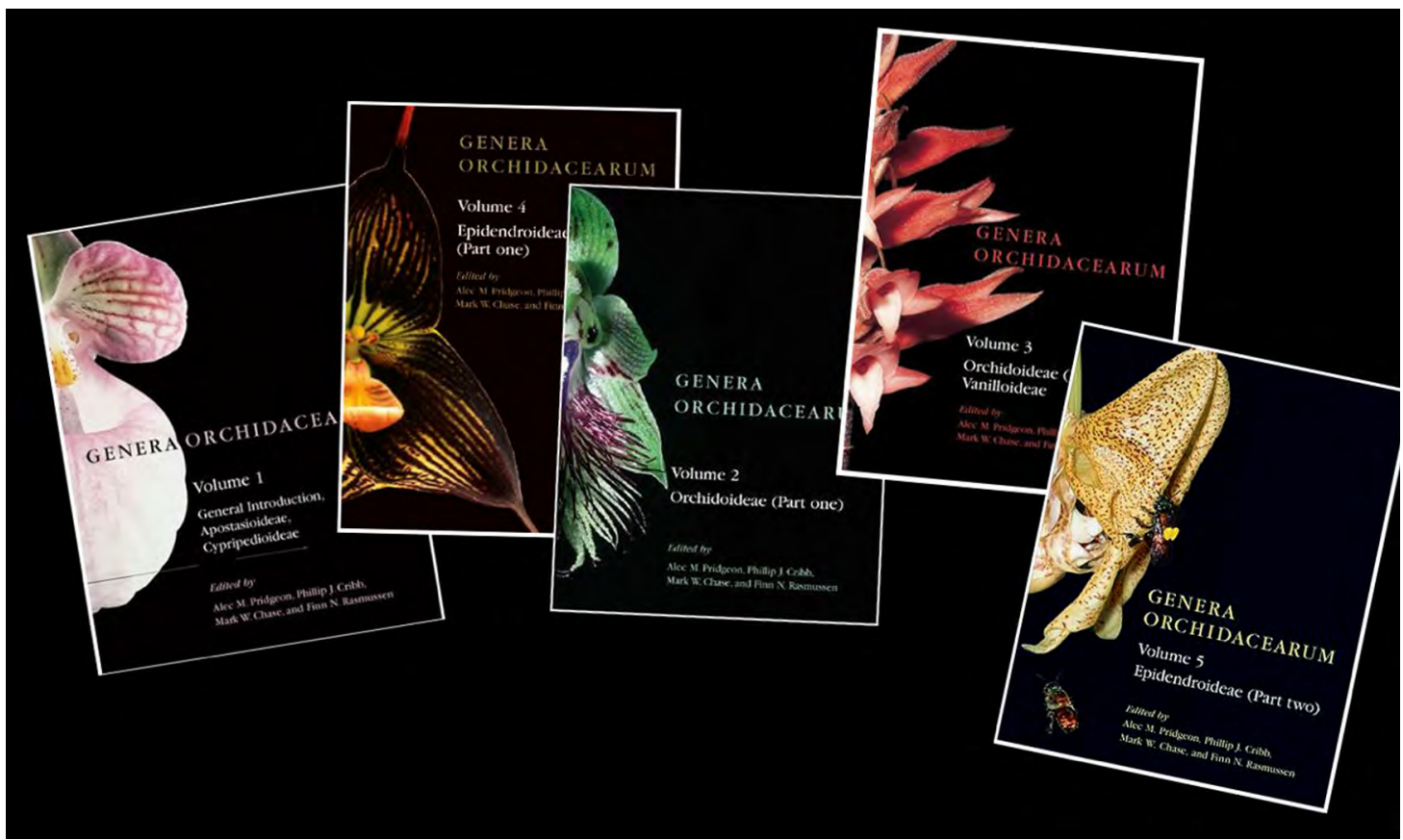

FIGURE 9. Generic circumscriptions adopted by Genera Orchidacearum constitute the systematic framework of EPIDENDRA.

scientists for years (Pridgeon et al. 1999, 2001, 2003 , 2005, 2009, in press) (Fig. 9). The editors invited several international specialists to contribute in their particular areas of expertise, to produce comprehensive treatments for each genus, with complete nomenclature, description, distribution, and summaries of our biological, ecologic, and economic knowledge. The first volume of the series saw the light in 1999, the second in 2001, and the third - including the second part of subfamily Orchidoideae and subfamily Vanilloideae - in 2003, just in time to be adopted as the general systematic framework of LBG's database. Since then, volumes 4 and 5 of Genera Orchidacearum (issued respectively in 2005 and at the end of 2009) presented the first two parts of the treatment of the largest subfamily of Orchidaceae, Epidendroideae, which also includes most Neotropical taxa. In particular, the last published volume includes treatments of 187 genera in tribe Cymbidieae. Many of the groups covered (like Maxillariinae and Oncidiinae) have been extensively reorganized in recent years, and the work updates accordingly generic circumscriptions and nomenclatural changes. In addition, the volume included an addendum with relevant nomenclatural changes in Laeliinae made since the publication of volume 4 , in which that subtribe was covered. The last volume of the series, volume 6 , covering mostly Paleotropical genera, is expected to be published in 2014.

Even though orchid systematics will probably remain in a fluid state for years in the future as new data are incorporated, the framework of Genera Orchidacearum has proven to be consistently and broadly accepted by the scientific and horticultural communities, greatly reducing the effort by the staff working at EPIDENDRA to make nomenclatural assumptions on several alternative taxonomic circumscriptions.

\section{Natural variation}

Botanists working in tropical areas have an opportunity to improve our knowledge of orchid diversity and to provide a bridge between systematic research and the general public, incorporating in their floristic databases other data that are not accessible to their colleagues in the developed nations, such as visual databases of specimens, slides, drawings, etc. Systematically associated with preserved vouchers, and often with their respective pollinaria, the photographs of flowers included in EPIDENDRA are not representative of the species but instead a faithful depiction of individual characteristics and a tool to understand 


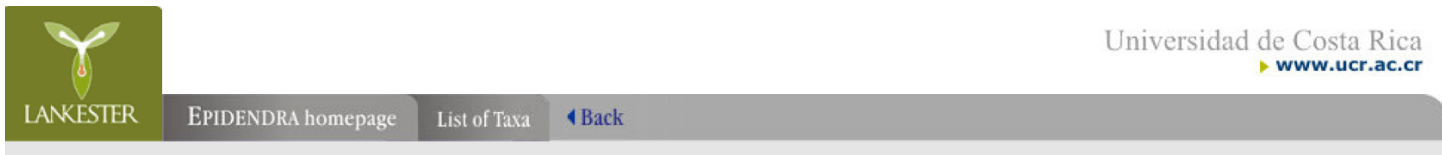

Kefersteinia parvilabris Schltr., Repert. Sp. Nov. Regni Veg. 19: 52. 1923.

TYPE: Costa Rica. San Jerónimo, Jan. 1922, C. Wercklé 116 [holotype, B, destroyed: lectotype, selected by Pupulin (2001), AMES 31623, drawings of the holotype].

\section{HOMOTYPIC SYNONYMS}

Chondrorhyncha parvilabris (Schltr.) L.O. Williams, Ceiba 5: 195. 1956.

Senghasia parvilabris (Schltr.) Szlach., J. Orchideenfreund 10(4): 336. 2003.

\section{HETEROTYPIC SYNONYMS \\ Kefersteinia deflexipetala Fowlie, Orchid Digest 30: 117. 1966.}

TYPE: Costa Rica. Cartago: Cedral de Orosi, 1400 m, C.H. Horich H64CR13 [holotype, LA (drawing of type); photo of paratype, AMES].

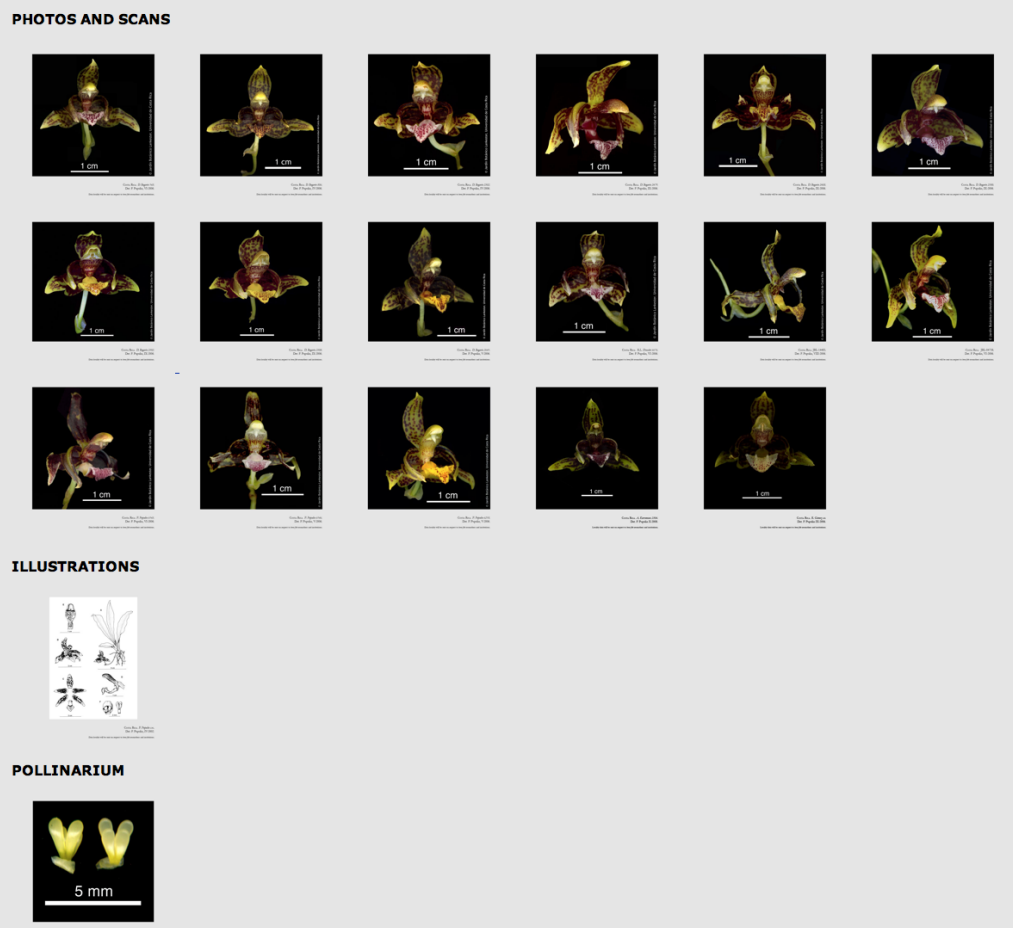

\section{EPIDENRA}

FIGURE 10. A page from the actual on-line version of EPIDENDRA. 


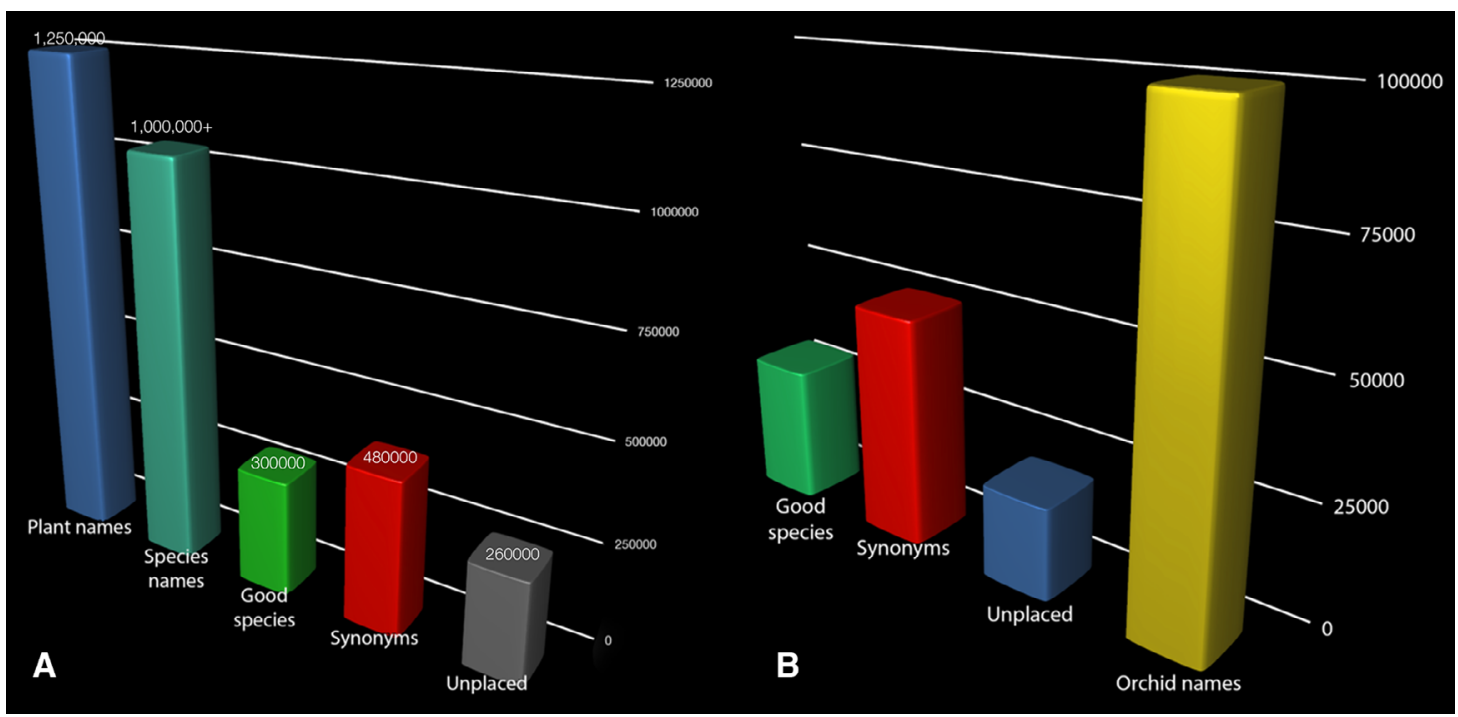

FIGURE 11. Published binomials in A) the plant kingdom, and B) Orchidaceae.

the natural variation of living organisms and improve our appreciation of specific circumscriptions (Pupulin 2009). Today, the database includes over 15,000 photographs and illustrations of orchid species. Looking at several files of EPIDENDRA such as those of Guarianthe skinneri (Bateman) Dressler \& W. E. Higgins or Kefersteinia parvilabris Schltr. (Fig. 10), one can easily understand why the taxonomy of tropical orchids, often based on the study of a single or a few specimens, is plagued by tens of thousands of synonymous names.

\section{A daunting task}

Dealing with the nomenclature and taxonomy of probably the largest family of angiosperms represents a serious commitment. Current figures for the plant kingdom suggest a grand total of 1,250,000 names, of which about one million are species names. Of these, however, almost half are synonyms, and more than 250,000 are unplaced for lack of information or taxonomic verification (WCSP 2012; Fig. 11A). An estimation of the orchid names to be included in EPIDENDRA accounts for almost 100,000 binomials. Of these, probably less than 30,000 are good species, at least 55,000 are synonyms, and some 15,000 require further study to be placed correctly in any of the categories (Fig. 11B). Even though EPIDENDRA concentrates mostly on Neotropical taxa, the task remains daunting, as orchid species from tropical regions of the Americas represents half of all Orchidaceae. With some 8,000 binomials actually included, EPIDENDRA only covers today about one-tenth of the published orchid names (Fig. 12). However, coverage is not random: almost $90 \%$ of the orchid taxa from Costa Rica are included and approximately $40 \%$ of all Orchidaceae of Mesoamerica, including Mexico. Particularly well represented are also the orchids of Panama, which constitute a definite target for LBG researchers. Through the strong relationship developed recently with the Andean Orchids Research Center in Ecuador, emphasis has been put on Ecuadorian and Andean taxa, particularly in the most diverse group, Pleurothallidinae Lindl. (Fig. 13A).

Of the 16,000 users who visit EPIDENDRA every year, 85\% come from Latin American countries. Of these, more than $40 \%$ are from Costa Rica and about $50 \%$ from Central America. Contacts from Colombia and Ecuador are most numerous from South America (5.5\% and $3.5 \%$, respectively), followed by visitors from Brazil (2.5\%). The most frequent non-Latin American visitors are from the United States (7.5\%), Germany $(3.5 \%)$ and the Netherlands (3\%).

\section{Where we are going from here}

That EPIDENDRA could continue offering to the scientific and horticultural communities a real service is mostly dependent on the reliability of data presented in its pages. Until now, this has been achieved by focusing the effort of data taxonomic verification (species names, protologues, images 


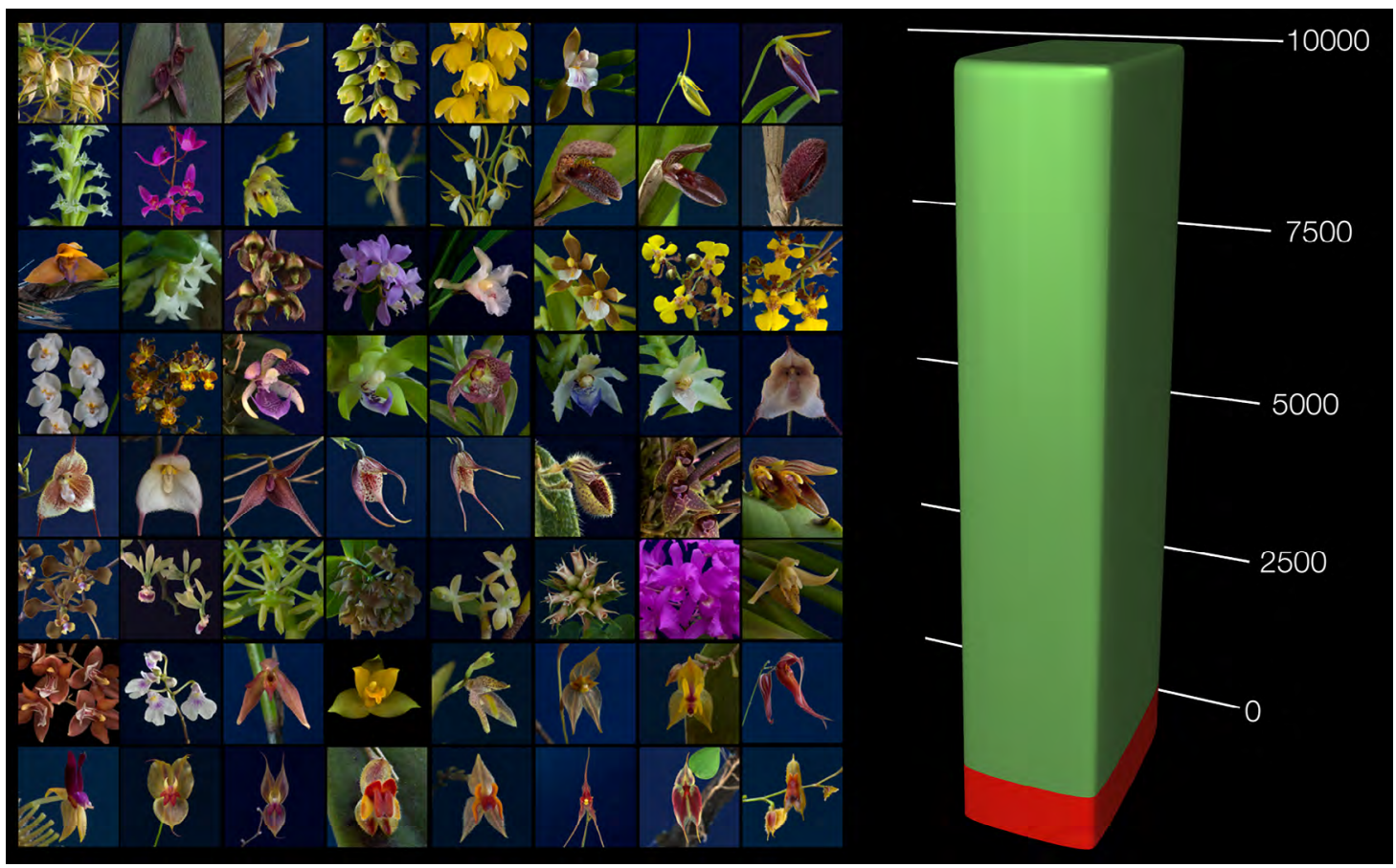

FIGURE 12. EPIDENDRA mostly includes records related to the orchid flora of the American tropics. With some 9,000 critically evaluated names, it covers today one-tenth of all Orchidaceae binomials.

of types, type illustrations, photographs and other illustrations) for those taxa that can be more easily studied at the center, both as living specimens and conserved vouchers, and on which the taxonomists of the LBG have more experience. Meanwhile, EPIDENDRA has been instrumental in the creation of a vast system of scientific agreements with other institutions and researchers. These include institutions that contributed digitized images of historically relevant materials and literature, as well as research centers and students that contribute their expertise in particular orchid groups or local floras (Fig. 14).

To expand geographic coverage of the database to embrace orchid floras of tropical regions of the Old World, and in particular the taxonomy of large groups as Bulbophyllum Thouars or Dendrobium Sw. or difficult species complexes as in the genera Ophrys L. and Dactylorhiza Neck. ex Nevski, the curators of EPIDENDRA need the scientific and technical support from a large group of experienced researchers across the world. Such expertise, in fact, should not be limited to the taxonomy of the involved taxa but would require other skills to nourish the network with a rich and varied imaging support.

Given its actual coverage and the needs of local researchers, the first regions towards which EPIDENDRA should expand are the West Indies and the Amazonian regions and Brazil in South America (Fig. 13B). In the Old World tropical regions, the orchid flora of Africa will have priority in the next years, as it is likely that local botanists and naturalists will need original documentary sources to interpret and identify their plants correctly. Orchid-rich tropical regions of Southeast Asia will eventually represent the last step to complete the database (Fig. 13C). The complex orchid floras of the temperate regions are a minor priority for the global taxonomic orchid network, as scientists who deal with them also usually have unrestricted access to documentary sources.

Right: Figure 13. Covering areas of EpIDENDRA (2012) and directions for development. A - Most represented in the database are taxa from Central America and Andean South America. B - The Antilles, Amazonian South America and Brazil are the most immediate target of the network. C - Orchid species from the Paleotropics represent a further development. 
A
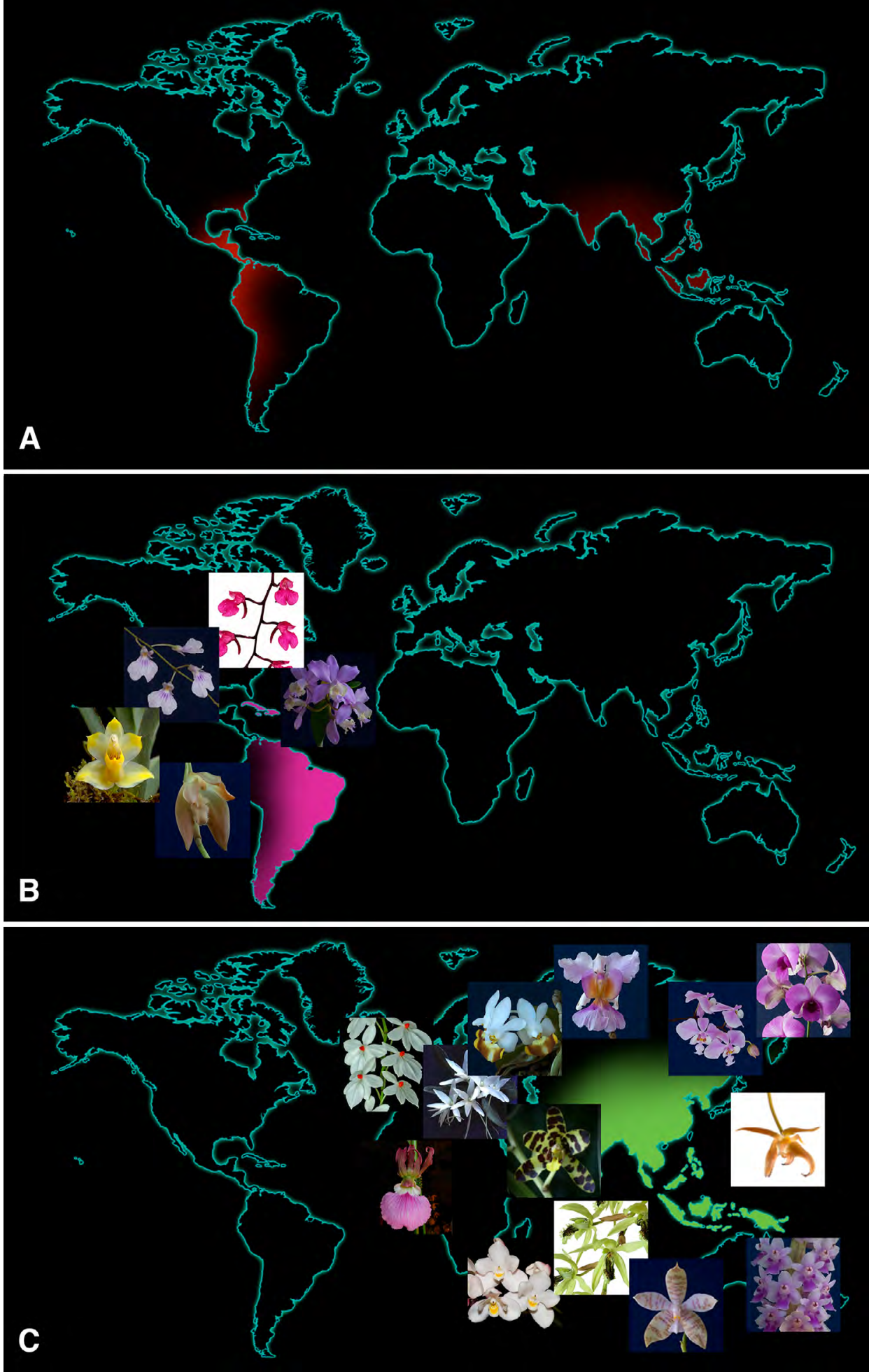


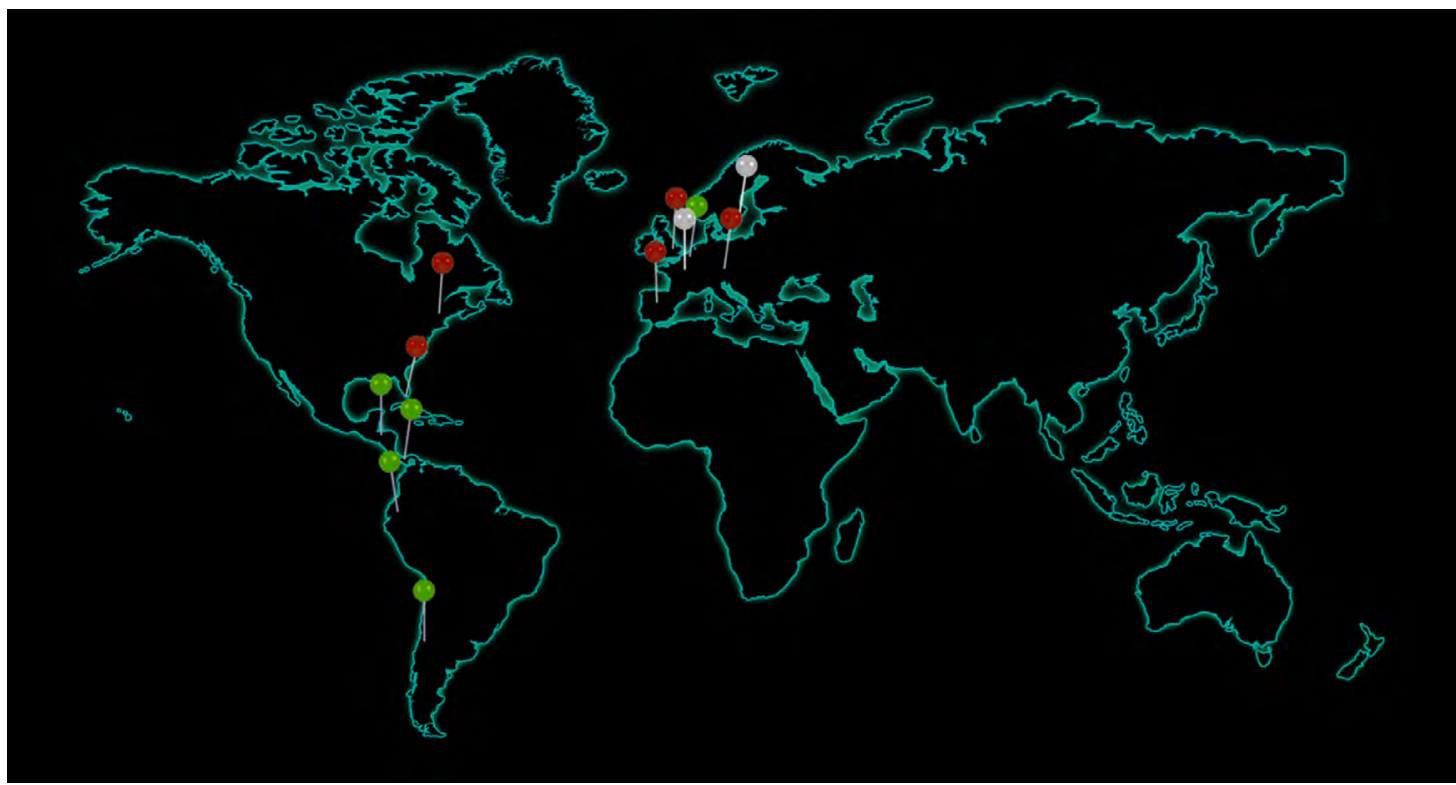

FIGURE 14. EPIDENDRA scientific network. Red dots indicate institutions that provide historical material and literature to the database. Green dots are centers providing expertise in particular groups. White dots are other institutions with which agreements for scientific cooperation are underway.

Progressive access to essential documents related to the orchid diversity of Costa Rica and other regions of Central America has enabled research staff at LBG to improve the quantity and quality of their taxonomic work significantly. The daily use of EPIDENDRA by a growing number of orchid researchers in the Latin America demonstrates that the documentary gap that slowed botanical activity in the tropics may be, and must be, left behind.

ACKNOWLEDGMENTS. I would thank all the people who participate to the conceptual discussion about the reasons and scopes of EPIDENDRA, and in particular Jorge Warner, Diego Bogarín, Daniel Jiménez, Hilda León-Páez, Carlos Ossenbach and Walter Schug. Gratitude is extended to my colleagues at LBG, Robert L. Dressler, Melania Fernández, Adam P. Karremans and Christina M. Smith, who daily improve the databases with their work. A special acknowledgment is due to the curators and staff of the herbaria and libraries that took part to the project in its ten years of activity: in particular to Gustavo A. Romero-González (AMES), Phillip J. Cribb (K), M. Velayos Rodríguez and M. R. Noya Santos (MA), Wesley E. Higgins and Bruce Holst (SEL), and Ernst Vitek (W). The project 814-BO-709 "EPIDENDRA: las bases de datos electrónicas de orquídeas del Jardín Botánico Lankester" is supported by the Vice-presidency of Research, UCR, which is warmly acknowledged here.

\section{LiTERATURE CITED}

Atwood, J. T. \& D. E. Mora-Retana. 1999. Orchidaceae: Tribe Maxillarieae: subtribes Maxillariinae and Oncidiinae. In: Burger, W. (ed.). Flora costaricensis. Fieldiana, Bot., n.s. 40: 1-182.

Barbosa Rodrigues, J. 1877. Genera et species orchidearum novarum. Rio de Janeiro, C. et H. Feiuss.

Barringer, K. 1986. Typification of Schlechter's Costa Rican Orchidaceae. I. Types collected by A. Brenes. Fieldiana, Bot. n.s. 17: 1-24.

Berendsohn, W. G. 1997. A taxonomic information model for botanical databases: the IOPI Model. Taxon 46: 283-309.

Conn, B. J. 2003. Information standards in botanical databases - the limits to data interchange. Telopea 10: 5360.

Gómez-Pompa, A. \& L. I. Nevling Jr. 1998. Some reflections on floristic databases. Taxon 37: 764-775.

IPNI. 2012. IPNI holdings, at http://www.ipni.org/stats. html, consulted December 2012.

Mello Leitão, C. de. 1937. A biologia no Brasil. São Paulo, Companhia Editora Nacional. Coleção Brasiliana: 99.

Neiva, A. 1929. Esboço histórico sobre a botânica e zoologia no Brasil. São Paulo, Sociedade Impressora Paulista.

Ossenbach, C. 2009. Orchids and orchidology in Central America: 500 years of history. Lankesteriana 9(1-2): 1-268. 
Ossenbach, C., F. Pupulin \& R. Jenny (eds.). In press. Orchids in the life and work of Auguste R. Endrés. 2 vol. Vienna, Verlag des Naturhistorischen Museums.

Pridgeon A. M., P. J. Cribb, M. W. Chase \& F. N. Rasmussen (eds.). 1999. Genera orchidacearum. Volume 1. General introduction, Apostasioideae, Cypripedioideae. Oxford, Oxford University Press.

Pridgeon A. M., P. J. Cribb, M. W. Chase \& F. N. Rasmussen (eds.). 2001. Genera orchidacearum. Volume 2. Orchidoideae (Part 1). Oxford, Oxford University Press.

Pridgeon A. M., P. J. Cribb, M. W. Chase \& F. N. Rasmussen (eds.). 2003. Genera orchidacearum. Volume 3. Orchidoideae (Part 2), Vanilloideae. Oxford, Oxford University Press.

Pridgeon A. M., P. J. Cribb, M. W. Chase \& F. N. Rasmussen (eds.). 2005. Genera orchidacearum. Volume 4. Epidendroideae (Part 1). Oxford, Oxford University Press.

Pridgeon A. M., P. J. Cribb, M. W. Chase \& F. N. Rasmussen (eds.). 2009. Genera orchidacearum. Volume 5. Epidendroideae (Part 2). Oxford, Oxford University Press.

Pridgeon A. M., P. J. Cribb, M. W. Chase \& F. N. Rasmussen (eds.). In press. Genera Orchidacearum. Volume 6. Epidendroideae (Part 3). Oxford, Oxford University Press.

Pupulin, F. 2007. EPIDENDRA, the botanical databases of Jardín Botánico Lankester at the University of Costa Rica. Pp. 178-180 in: F. Pupulin (ed.). Proceedings of the $3^{\text {rd }}$ International Orchid Conservation Congress - IOCC, San José, Costa Rica, March 2007. Lankesteriana 7(1-2).

Pupulin, F. 2009. EPIDENDRA, the on-line botanical databases of Jardín Botanico Lankester. Orchids 78(3): 138-139.
Pupulin, F. 2010. Orchidaceae werckleanae: typification of Costa Rican orchid species described from collections by K. Wercklé. Bot. J. Linn. Soc. 163: 111-154.

Pupulin, F. \& G. A. Romero. 2003. Costa Rican Orchidaceae types (CROTYPES) digital imaging documentation at AMES, Harvard University. Pp. 11-16 in: F. Pupulin (ed.). Proceedings of the $1^{\text {st }}$ International Conference on Neotropical Orchidology, San José, Costa Rica, 2003. Lankesteriana 3(2).

Pupulin , F. \& J. Warner. 2005. Know your orchids. A botanical garden rich in information serving a country rich in flora. Orch. Res. Newsletter 6: 5-8.

Sá, M. R. 2001. O botânico e o mecenas: João Barbosa Rodrigues e a ciência no Brasil na segunda metade do século XIX. Hist. Ciênc. Saúde Manguinhos 8(suppl.): 899-924.

Schlechter, R. 1923. Beiträge zur Orchideenkunde von Zentralamerika, II. Additamenta ad Orchideologiam Costaricensem. Repert. Sp. Nov. Regni Veg. Beih. 19: 3-307.

Schug, W. 2003. El Centro de Documentación del Jardín Botánico Lankester. Pp. 21-24 in: F. Pupulin (ed.). Proceedings of the $1^{\text {st }}$ International Conference on Neotropical Orchidology, San José, Costa Rica, 2003. Lankesteriana 3(2).

Standley, P. C. 1937. Flora of Costa Rica. Part 1. Field Museum of Natural History. Bot. Ser. 18.

Tropicos. 2012. Tropicos Home, at http://www.tropicos.org, consulted December 2012.

WCSP. World Checklist of Selected Plant Families. Facilitated by the Royal Botanic Gardens, Kew. Published on the Internet; http://apps.kew.org/wcsp/ Retrieved December 2012. 